\title{
Linkages Between Stock \& Commodity Indices: An Empirical Investigation
}

\author{
Effulgence \\ Vol. 16 No. 1 \\ January - June, 2018 \\ Rukmini Devi Institute of Advanced Studies \\ E-mail : effulgence@rdias.ac.in, Website : www.rdias.ac.in \\ http:/ / effulgence.rdias.ac.in/user/default.aspx \\ https://dx.doi.org/10.33601/effulgence.rdias/v16/i1/2018/82-93
}

\author{
Dr. Rakesh Shahani ${ }^{1}$ \\ Madhav Tiwari ${ }^{2}$ \\ Anuj Miglani ${ }^{3}$
}

\begin{abstract}
The present study makes an attempt to investigate the linkages between movement of the NSE Nifty (stock index) and MCX Comdex Futures (Commodity Index). The study period is five years (April 2012 to March 2017, daily closing prices). The econometric tools used in the study include JB Normality test, Unit root ADF, Granger Causality, Engle Granger \& Johansen Co-integration Tests \& Vector Autoregressive Model (VAR). The result of the study showed that both indices under study were I(1) stationary. The Co-integration test results showed that the two indices were not co-integrated. The VAR results showed that each index was a function of its own lag; MCX COMDEX till lag '2' while NSE Nifty till Lag '3'. Granger Causality which was run at first difference showed that positive Causality flowing from NSE Nifty to MCX COMDEX, but not vice versa.
\end{abstract}

Keywords: MCX Comdex Futures, Engle Granger Co-integration, Vector Autoregressive Model, Unit root ADF.

\section{INTRODUCTION}

$\mathrm{T}$ he relation between financial markets and commodity markets has been one of the active areas of interest to the researchers over the last two decades. Although there is a significant difference between stocks and commodities from the point of view that commodities are backed by physical

1. Associate Professor (Business Economics), Dr. Bhim Rao Ambedkar College (University. of Delhi), rakesh.shahani@gmail.com

2. Student, BA(H) Business Economics, Dr. Bhim Rao Ambedkar College (University. of Delhi), madhavt28@gmail.com

3. Student, BA (H) Business Economics, Dr. Bhim Rao Ambedkar College (University. of Delhi), anujmiglani23@gmail.com

Corresponding Author

Dr. Rakesh Shahani, Associate Professor (Business Economics), Dr. Bhim Rao Ambedkar College (University. of Delhi), rakesh.shahani@gmail.com 
products which require storage and transportation, stocks on the other hand do not have such a character and are typical financial products. (Siqueira, E. L., Stosic T., Bejan, L., \& Stosic B. (2010) Over the last decade, there has been rapid growth in commodity markets in terms of liquidity and a lot of investors are now getting attracted to commodities purely from investment point of view rather than as a hedging tool to support "real" economic activity (Vivian and Wohar, 2012 ).

Many researcher believe that commodities have low correlation with the stock markets and therefore must be included in an investors' portfolio as a component of effective diversification of funds, (Shahani Rakesh 2011). On the other hand these so called low correlations typically breaks down during times of crisis, this was seen in the global crisis of 2008 when all asset classes including stocks and bonds, commodities and real assets showed sharp decline in prices (Chan, K. F., Treepongkaruna, S., Brooks, R., \& Gray, S.,2011).

In light of the above, an attempt has been made in the present study to investigate the linkages between stocks and commodities in Indian context by taking daily closing prices on two important indices; the NSE Nifty (stock index) and MCX Comdex Futures (Commodity Index) for the five year period; April 2012-March 2017. Both the Indices under study are the Flagship indices; whereas the MCX Comdex is computed as simple weighted average of the three of the exchanges group indices on the MCX Commodity Exchange viz. MCX Energy, MCX Metals \& MCX Agri, the NSE Nifty, is the fifty share stock index \& covers 12 sectors which is approximately $63 \%$ of total free float market cap on the exchange. (www.nseindia.com, www.mcxindia.com). Coming to the period of the study, the study tries to capture the relation between the variables by analyzing the daily closing prices for the period April 2012-March 2017, the choice of the period of study was made keeping into consideration the fact that the study period must be a relatively stable period on financial markets.

\section{REVIEW OF LITERATURE}

The literature review gives a summary of some of the recent studies in the area of linking stock markets with commodity markets. Majority of the studies explored in this area ; Berlia, N., \& Sehgal, S. (2013), Mensi, W., Beljid, M., Boubaker, A., \& Managi, S. (2013) Thuraisamy, K. S., Sharma, S. S., \& Ahmed, H. J. A. (2013)\& Kumar, B., \& Pandey, A. (2011) have focused on volatility spill over impact from commodities market to stocks and vice versa to another with the cross country correlations being explored by using the DCC \& BEKK GARCH Models. Very few studies have however demonstrated clearly the return movement and its relationship amongst the two markets. Some of the studies (Belke, A., Bordon, I. G., \& Hendricks, T. W. 2010).have used the autocorrelations amongst stocks vs. commodities \& how were the commodities impacted by macro policies autocorrelations. The overall volatility relation between the commodity and stock markets have shown a somewhat mixed picture ;some authors proving that volatility travels from commodities to stocks which was countered by other researchers. In terms of the relation it is interesting to note that high percentage of these studies have focused on specific commodities like Oil, Gold and its relation with the stock market movements rather than exploring the broader commodity indices.

Berlia, N., \& Sehgal, S. (2013) investigated for evidence of transmission of information between Indian futures commodities markets and World Commodities Markets [(e.g. LME (UK), COMEX (USA) \& SHFE (CHINA)].The test of co-integration applied was Gregory Hansen test which could in addition capture the structural breaks in time series. On similar pattern the unit root test of Zivot Andrews test was also used in the study. The spillover effect of volatility was tested with the help of BEKK GARCH Model. The co-integration tests showed that long term co-integration did exist between most commodity markets, the spill-over results proved the dominance of LME for Metals 
while the dominance of Indian MCX was mainly in Silver. Mensi, W., Beljid, M., Boubaker, A., \& Managi, S. (2013) modelled volatility transmission between stock index \& commodity indices using VAR-GARCH model for the eleven year period 20002011. The results showed significant volatility transmission among the stock index S\&P 500 and commodity markets. The significant influence of stock index S\&P 500 was seen on the oil and gold markets. These results have a strong implication for stock portfolio managers to include commodities in their portfolio

Creti, A., Joets, M., \& Mignon, V. (2013) studied the relation between returns for twenty five stocks and commodities for eleven years (January 2001 to November 2011) and the tool used was Dynamic Conditional Correlation GARCH.. The results showed that the correlations between stock markets \& commodities have actually evolved over time, these were at peak during the 2008 crisis, but were also highly volatile. Further results showed that when stock markets are bullish, correlations are also growing but these diminish when the markets are falling. Also after studying the behaviour of returns amongst commodities it could be said that although commodities share some common features with stocks therefore the two assets must not be considered as a single homogeneous asset class. Thuraisamy, K. S., Sharma, S. S., \& Ahmed, H. J. A. (2013) made a study of spill-over effects between volatility in 14 Asian equity market \& volatility of crude oil \& gold futures using bivariate BEKKGARCH $(1,1)$. The results showed that in established \& mature equity markets like Japan there is an indication of spillover from equity to commodity markets (crude, gold) while it was just the opposite in immature markets or spillover effects move from commodity futures to equity. Specific country results showed that for three countries namely Malaysia, India, \& South Korea there was evidence of bidirectional spillover between equity markets and oil futures while there is bi directional spillover between gold and equity markets in case of China \& Philippines. Thus it can easily be seen that volatility of gold futures is equally important as that of oil futures.

Kumar, B., \& Pandey, A. (2011) tried to examine the cross market linkages between nine commodities belonging to different sectors in India. The time series tests which were applied included Causality, Co-integration and error correction. The spill-over effect was tested using the BEKK GARCH Model. The results proved that there was COINTEGRATION between movement in commodities in world markets and it also resulted in impacting Indian commodity markets in considerable manner. The spill over impact of London Metal Exchange (LME) on India's MCX was much stronger than MCX on LME. Chan, K. F., Treepongkaruna, S., Brooks, R., \& Gray, S. (2011) studied the conditional joint distribution of returns of different type of assets like stocks \& bonds, oil, gold \& real estate with an angle of portfolio diversification and asset allocation. The model used to examine returns was Markov regimeswitching model. The two regimes were identified as : "tranquil" regime \& "crisis" regime, the tranquil regime showed positive stocks returns with lower volatility \& flight from gold to stocks. However the crisis regime was characterized by sharp negative returns in stocks with high volatility \& there was evidence of contagion between oil, stocks, \& real estate with a flight from stocks to Treasury bonds.

Siqueira, E. L., Stosic T., Bejan, L., \& Stosic B. (2010) investigated using De-trended CrossCorrelation Analysis technique, the auto \& cross correlations relating to the time series volatility time series in stock market of Brazil. The results showed that stock autocorrelations were weaker than that of Commodities. Further the results of cross correlation showed that these were stronger than that of combination of individual series autocorrelations Belke, A., Bordon, I. G., \& Hendricks, T. W. (2010) empirically examined the inter-linkages between, consumer prices, commodity prices \& money supply for the period of 38 years for major OECD countries. The study results showed that money supply gives some useful information about future commodity 
prices, the results were robust as they are stable and passed a series of recursive tests. The conclusion therefore was liquidity is an indicator of future commodity price. The approach used in the study was co-integrating VAR framework.

As already mentioned in the beginning of the review of literature, that there is a good percentage of existing studies which have seen the two variables; commodities and stocks from the volatility spill-over angle \& also there has been an increased focus on testing the relation between stock indices on one hand and specific commodities like Crude, Precious Metals (Gold, Silver) on the other. To this end our viewpoint is that any meaningful comparison \& establishing any kind of inter relationship between financial instruments requires the instruments to revolve around common feature \& characteristics. Thus if one considers a stock index which is a weighted average of key stocks, it must be compared with another index of similar nature and this is what has been our focus of our study where we have identified the two indices as NSE Nifty, a flagship index of NSE with fifty shares \& MCX Comdex, a commodity index which is the weighted average of Energy, Agriculture \& Metals. Further the approach of the paper has been to study their co-movement of returns under a VAR framework using cointegration \& causality approaches.

\section{DATA \& ECONOMETRIC TOOLS USED IN THE STUDY}

The period of study has been taken to be five years April 2012 to March 2017 and the study tries to capture the relation between NSE Nifty (stock index) and MCX Comdex Futures (Commodity Index) by taking the daily closing prices for the two indices(variables) (total no. of observations are 1236). The data sources include websites of MCX (www.mcxindia.com), NSE (www.nseindia.com) \& Yahoo Finance (), the time series analysis has been carried both at levels \& on first differenced data. The econometric tools which have been applied in our study include (a) Augmented Dickey Fuller (ADF) test of Stationarity of Variables (b) Engle Granger two stage \& Johansen test for Co-integration of variables (c) Granger Causality (d) Establishing a VAR Model with AIC Optimal Lag Length Criteria (e) A R Characteristic Roots for VAR Stability.

\section{METHODOLOGY ADOPTED}

\section{(i) Test for Normality of Data}

The Statistical Description of two variables under study viz. MCX Comdex Futures (Commodity Index) \& NSE Nifty (stock index) is given below in Table 1(i) \& 1(ii) respectively. The table gives Mean, Median, Standard Deviation, Skewness and Kurtosis of two distributions. It also gives the JB Statistic which is a test for normality of data

Table 1 (i) : Statistical Description of MCX Comdex Futures

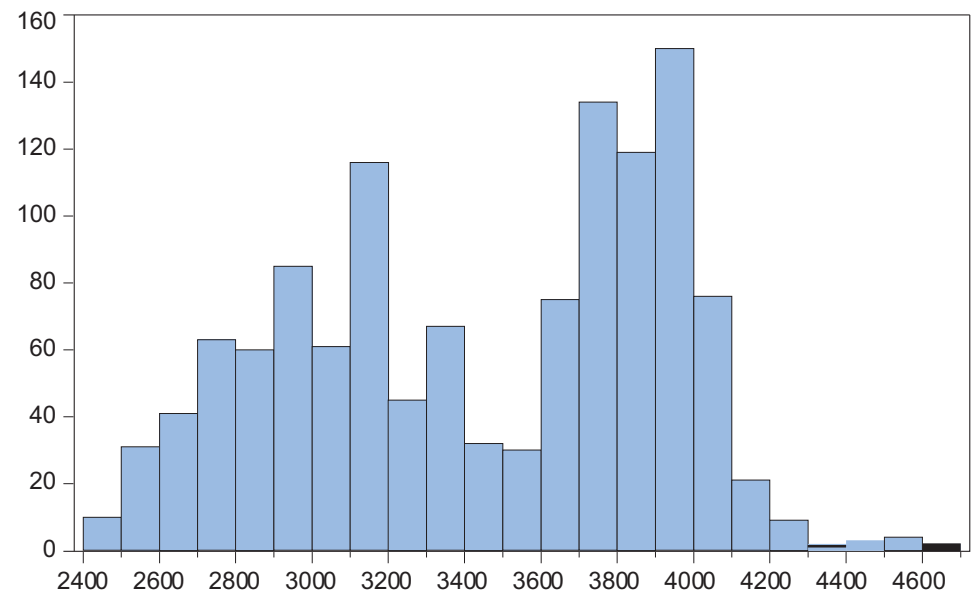

Series: MCX_COMDEX Sample 4/02/2012 3/31/2017 Observations 1236

Mean Median Maximum Minimum Std. Dev. Skewness Kurtosis

Jarque-Bera Probab ility
3441.823

3529.905

4689.600

2450.400

477.3787

$-0.210620$

1.875263

74.28755

0.000000 
Table 1 (ii): Statistical Description of NSE Nifty

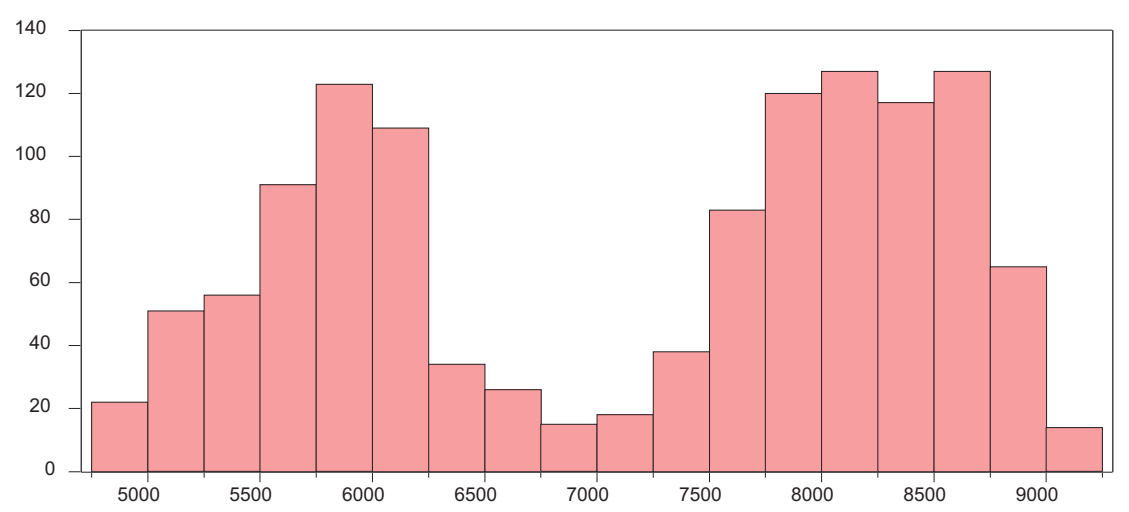

\begin{tabular}{|lc|}
\hline Series: NSE_NIFTY \\
Sample 4/02/20123/31/2017 \\
Observations 1236 \\
Mean & 7172.802 \\
Median & 7613.425 \\
Maximum & 9173.750 \\
Minimum & 4835.650 \\
Std. Dev. & 1254.654 \\
Skewness & -0.236813 \\
Kurtosis & 1.533767 \\
& \\
Jarque-Bera & 122.2693 \\
Probability & 0.000000 \\
\hline
\end{tabular}

The statistical description of the two variables clearly reveal that out of the two NSE Nifty Prices are more volatile than the MCX Comdex as its Standard Deviation is almost three times the Standard Deviation of MCX Comdex. Further both distributions are negatively skewed, both have Jarque Bera (JB) Statistics much higher than what is required for a normal distribution (Normal JB* <5.99). This is also evident from the two histograms whereby the histogram of MCX Comdex \& NSE Nifty, none of these are close to the typical bell shaped normal distribution curve. JB test have been computed using the following formula $(\mathrm{S}=$ Skewness, $K=$ Kurtosis and ' $n$ ' no. of observations)

$$
J B=\frac{n}{6}\left(S^{2}+\frac{1}{4}(K-3)^{2}\right)
$$

Null Hypothesis for Normality: The time series is normal

Test Statistic: Jarque Berra

Acceptance / Rejection Criteria*: accept the null, if computed JB value $<5.99$ (value of Chi square at 2 df)

\section{(ii) Testing the Stationarity of Variables}

We apply Augmented Dickey Fuller (ADF) test (with intercept) to find out the stationarity of our variables namely; NSE Nifty (stock index) and MCX Comdex Futures (Commodity Index). We use the following equations (i \& ii) for this purpose.

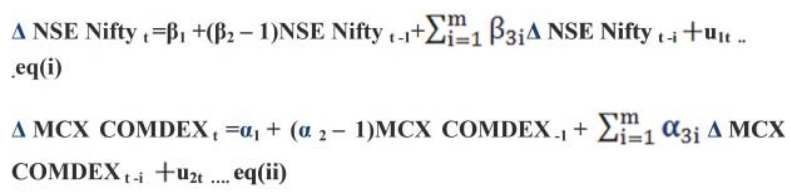

(Note: For equation (I); The variable for which we are testing stationarity is NSE Nifty. $\Delta$ NSE Nifty $t$ is change in NSE Nifty in period $t,\left(\beta_{2}-1\right)$ is the coefficient of the Stationarity for variable, $\sum_{i=1}^{m} \beta_{3 i}$

$\Delta$ Ret NSE Nifty $t_{t-i}$ denotes change in NSE Nifty in period $\mathrm{t}-\mathrm{i} \&$ is the augmented variable which has been added to take care of auto correlation and the term adds up ' $\mathrm{m}$ ' times till the auto correlation is removed, $u 1 t$ is random error term. Similarly we carry out stationarity test for our eq (ii) namely the MCX COMDEX using explanation as given for equation (i) )

The testable hypothesis for our Stationarity test of our Variable NSE Nifty (eq (I)) would be

Null Hypothesis $\left(\mathrm{H}_{0}\right): \beta_{2}-1=0$ Or $\beta_{2}=1$ (the NSE Nifty is not stationary)

Alt Hypothesis $\left(\mathrm{H}_{\mathrm{a}}\right): \beta_{2}-1<0$, (NSE Nifty is stationary)

We are testing at one tail only as we want to avoid the explosive process

\section{(iii) Testing the Co-integration of Variables}

The results of our Unit Root tests reveal that both our variables namely NSE Nifty and MCX COMDEX are stationary only at return and not at levels. 
Therefore next we must test whether or not there is any co-integration between the variables. The test of co-integration which we have employed in our study is Engle Granger Co-integration which tries to prove co-integration by testing the residuals i.e. whether the residuals are I (0) Stationary or not.

Null Hypothesis (Ho): Non Stationarity of residuals Alternate Hypothesis $\left(\mathrm{H}_{\mathrm{a}}\right)$ : Stationarity of residuals Here we first compute the residual error terms by running OLS on co-integrating variables (see eq (iii) \& eq (iv))

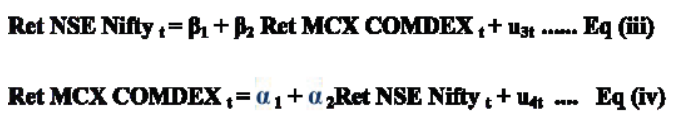

Running a second OLS of residuals as under:

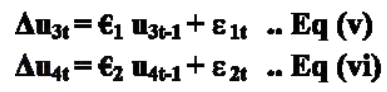

The results of the Engle Granger test are confirmed by applying Johansen Co-integration test

\section{(iv) The VAR Model \& test for Causality}

The results of our co-integration analysis (given later) show that the two variables Nifty and MCX COMDEX are not co-integrated. We therefore set up a VAR Model at first difference of the two variables:-

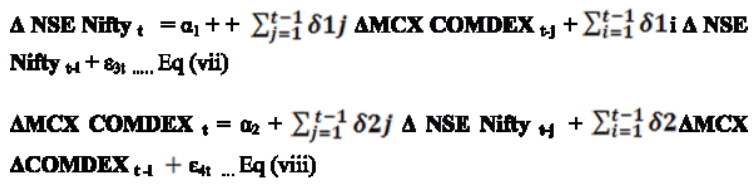

\section{RESULTS, DISCUSSION \& INFERENCES}

(a) Results of Unit Root Tests of our variables

Table 2 (i): Test for stationarity (Levels \& First Difference) for NSE Nifty

\begin{tabular}{|c|c|c|c|}
\hline \multirow{2}{*}{\multicolumn{4}{|c|}{$\begin{array}{l}\text { Null Hypothesis: CLOSE NSE Nifty has a unit root (Null for level) } \\
\text { Null Hypothesis: D CLOSE NSE Nifty has a unit root (Null for First Difference) } \\
\text { t-Statistic ' } p \text { 'Value. }\end{array}$}} \\
\hline & & & \\
\hline Level & Augmented Dickey-Fuller test statistic & -0.916372 & 0.7834 \\
\hline 1st Difference & Augmented Dickey-Fuller test statistic & -32.35662 & 0.0000 \\
\hline
\end{tabular}

[Test critical values 1\% level (-3.433969), 5\% level (-2.863025)]

Table 2 (i) results of stationarity of NSE Nifty show that the Presence of Unit root is accepted at levels (Computed $\mid{ }^{\prime} \mathrm{t}$ ' $\mid$ value of $0.916372<\left.1 \%\right|^{\prime} \mathrm{t}$ ' | tau (3.43). The same resulted can be seen with ' $\mathrm{p}$ ' value being 0.7834 where we accept the Null Hypothesis of Non Stationary data. The results of Unit root test for first difference show that the Presence of Unit root is rejected at first difference (Computed $\mid{ }^{\prime} \mathrm{t}$ ' $32.35662>\left.1 \%\right|^{\prime} t^{\prime} \mid$ tau (3.43) The same resulted can be seen with ' $\mathrm{p}$ ' value being 0.000 where we reject the Null Hypothesis of Non Stationary data The lags to remove autocorrelation are identified as ' 0 ' to get the best AIC Model.

Table 2 (ii): Test for stationarity (Levels \& First Difference) for MCX COMDEX

\begin{tabular}{|c|c|c|c|}
\hline $\begin{array}{l}\text { Null Hypothe } \\
\text { Null Hypothe }\end{array}$ & $\begin{array}{r}\text { CLOSE MCX COMDEX has a unit root (I } \\
D \text { CLOSE MCX COMDEX has a unit root } \\
\text { t-Statistic ' } p \text { ' Vo }\end{array}$ & $\begin{array}{l}\text { ill for level) } \\
\text { Null for Fir } \\
\text { ue. }\end{array}$ & \\
\hline Level & Augmented Dickey-Fuller test statistic & -1.333505 & 0.6158 \\
\hline $1^{\text {st }}$ Difference & Augmented Dickey-Fuller test statistic & -35.50682 & 0.0000 \\
\hline
\end{tabular}

[Test critical values 1\% level (-3.433969), 5\% level (-2.863025)] 
The results of stationarity tests for MCX COMDEX which are given in Table 2 (ii) are similar to those of NSE Nifty. Presence of Unit root is accepted at levels (Computed $\left|' t^{\prime}\right|$ value of $1.333505<\left.1 \%\right|^{\prime} t^{\prime} \mid$ tau (3.43). The same resulted can be seen with ' $p$ ' value being 0.6158 where we accept the Null Hypothesis of Non Stationary data. The first difference results however reject the unit root and accept stationarity of time series data (Computed $\mid{ }^{\prime} \mathrm{t}$ ' of $35.50682>1 \%$ $\left|{ }^{\prime} t^{\prime}\right|$ tau (3.43) The lags to remove autocorrelation are identified again as ' 0 ' to get the best AIC Model

(b) Results of Tests for Co-integration

We have applied two stage Engle Granger Cointegration Procedure for testing whether our variables MCX COMDEX and NSE Nifty are cointegrated. The results are given in Table 3 below

Table 3 (a): Regression results for co integration of MCX COMDEX and NSE Nifty (Two Step Engle Granger)

\begin{tabular}{|l|l|l|}
\hline Co-integrating Variables & ${ }^{\prime} \boldsymbol{t}_{c a l}{ }^{\prime}$ of coefficients & $\begin{array}{l}\text { Critical Value of Engle } \\
\text { Granger@1\% level }\end{array}$ \\
\hline MCX COMDEX (Dependent) & -1.606847 & -2.589 \\
\hline NSE Nifty (Dependent) & -1.294265 & -2.589 \\
\hline
\end{tabular}

Decision Criteria: If computed value is more negative that table value, we reject the null and say that the variables are co-integrated. The results clearly show that the two variables are NOT co-integrated or we accept the Null of No Co-integration.

Table 3 (b): Regression results for Co integration Johansen Method

Unrestricted Co-integration Rank Test (Trace)

\begin{tabular}{ccccc}
\hline Hypothesized & & Trace & 0.05 & \\
No. of CE(s) & Eigenvalue & Statistic & Critical Value & Prob. $^{* *}$ \\
\hline None & 0.006090 & 8.817310 & 15.49471 & 0.3826 \\
At most 1 & 0.001036 & 1.279152 & 3.841466 & 0.2581 \\
\hline
\end{tabular}

Unrestricted Co-integration Rank Test (Maximum Eigenvalue)

\begin{tabular}{ccccc}
\hline Hypothesized & & Max-Eigen & 0.05 & \\
No. of CE(s) & Eigenvalue & Statistic & Critical Value & Prob.** $^{*}$ \\
\hline None & 0.006090 & 7.538158 & 14.26460 & 0.4276 \\
At most 1 & 0.001036 & 1.279152 & 3.841466 & 0.2581 \\
\hline
\end{tabular}

Both Trace test \& Eigen Value indicate no co-integration at the 0.05 level 
Next since our time series (both variables) is neither stationary at $\mathrm{I}(0)$ nor Co-integrated, we may set up a VAR Model after checking for the lag structure (see Table IV Below) \& subsequently we can apply Causality test procedure by taking the first difference of the variables.

\section{(c) Identifying the most appropriate model (for the VAR Model)}

The results of the lag structure for our VAR (Table 4 below) gives the no. of lags for a model to be optimal (most appropriate). The results reveal that out of the five criteria that have been used in the study to determine the model optimality viz. LR, FPE, AIC, SC \& HQ, three of these criteria have identified as lag ' 5 ' as optimal while remaining two have identified lag ' 2 ' as most optimal (the same has been highlighted \& underlined in table IV below). Going with the majority (which also includes the most popular criteria; AIC), let us consider lag ' 5 ' as optimal while establishing our VAR model.

TABLE 4: VAR Lag Order Selection Criteria

\begin{tabular}{cccccc}
\hline Lag & LR & FPE & AIC & SC & HQ \\
\hline 0 & NA & $1.85 \mathrm{e}+11$ & 31.61949 & 31.62782 & 31.62262 \\
1 & 13109.49 & 4191755. & 20.92438 & $\underline{\mathbf{2 0 . 9 4 9 3 7 ^ { * }}}$ & $\underline{\mathbf{2 0 . 9 3 3 7 8 *}}$ \\
2 & 12.64092 & 4175768. & 20.92056 & 20.96220 & 20.93623 \\
3 & 11.40923 & 4163970. & 20.91773 & 20.97603 & 20.93967 \\
4 & 5.117499 & 4173629. & 20.92005 & 20.99500 & 20.94825 \\
5 & $\underline{\mathbf{1 5 . 5 9 1 1 1} *}$ & $\underline{\mathbf{4 1 4 7 4 3 4 . *}}$ & $\underline{\mathbf{2 0 . 9 1 3 7 5 *}}$ & 21.00536 & 20.94822 \\
6 & 5.913442 & 4154275. & 20.91540 & 21.02366 & 20.95613 \\
7 & 3.474045 & 4169473. & 20.91905 & 21.04397 & 20.96605 \\
8 & 2.131617 & 4189348. & 20.92381 & 21.06538 & 20.97707 \\
\hline
\end{tabular}

* indicates lag order selected by the criterion

LR: sequential modified LR test statistic (each test at $5 \%$ level)

FPE: Final prediction error

AIC: Akaike information criterion

SC: Schwarz information criterion

HQ: Hannan-Quinn information criterion

\section{(d) The VAR Framework Results}

The VAR estimates at first difference (which have been established on the basis of the order selection criteria given in Table 4 above) reveal that MCX COMDEX is a function of its own lags till lag ' 2 ' (Significant ' $t$ ' values given in parenthesis are highlighted ). On the other hand MCX COMDEX is also being determined by Lag ' 4 ' and Lag ' 5 ' of the other variable NSE Nifty, but not by recent lags of
NSE Nifty. This simply reflects the inefficiencies in transmission of information from one market to another. It also shows delayed assimilation of information by the MCX COMDEX. On the other hand the movement of the variable NSE Nifty is determined by its own Lag only and this is significant till Lag ' 3 '. The VAR framework results are discussed in Table 5 below. 
TABLE 5 : VAR Regression Results

Included observations: 1231 after adjustments t-statistics in [ ]

\begin{tabular}{|c|c|c|}
\hline & MCX_COMDEX & NSE_NIFTY \\
\hline \multirow[t]{2}{*}{ MCX_COMDEX(-1) } & 0.987464 & -0.028859 \\
\hline & [ 34.5391] & {$[-0.45173]$} \\
\hline \multirow[t]{2}{*}{ MCX_COMDEX(-2) } & 0.081655 & 0.061398 \\
\hline & [ 2.03684] & [ 0.68539] \\
\hline \multirow[t]{2}{*}{ MCX_COMDEX(-3) } & -0.051254 & -0.132496 \\
\hline & {$[-1.27788]$} & {$[-1.47834]$} \\
\hline \multirow[t]{2}{*}{ MCX_COMDEX(-4) } & -0.074410 & 0.123685 \\
\hline & {$[-1.85664]$} & [ 1.38108$]$ \\
\hline \multirow[t]{2}{*}{ MCX_COMDEX(-5) } & 0.050282 & -0.016928 \\
\hline & [ 1.76367$]$ & {$[-0.26571]$} \\
\hline \multirow[t]{2}{*}{ NSE_NIFTY(-1) } & 0.020431 & 1.087340 \\
\hline & [ 1.59169$]$ & [ 37.9094] \\
\hline \multirow[t]{2}{*}{ NSE_NIFTY(-2) } & -0.018543 & -0.152108 \\
\hline & {$[-0.97756]$} & {$[-3.58857]$} \\
\hline \multirow[t]{2}{*}{ NSE_NIFTY(-3) } & 0.009714 & 0.089746 \\
\hline & [ 0.51085] & [ 2.11218] \\
\hline \multirow[t]{2}{*}{ NSE_NIFTY(-4) } & -0.051756 & -0.076300 \\
\hline & $\begin{array}{r}(0.01893) \\
{[-2.73438]}\end{array}$ & $\begin{array}{r}(0.04230) \\
{[-1.80397]}\end{array}$ \\
\hline \multirow[t]{2}{*}{ NSE_NIFTY(-5) } & 0.038032 & 0.051701 \\
\hline & [ 2.95798] & [ 1.79952] \\
\hline \multirow[t]{2}{*}{$\mathrm{C}$} & 36.25209 & -22.97912 \\
\hline & [ 2.50825] & {$[-0.71151]$} \\
\hline
\end{tabular}

\section{(e) The VAR Stability test Results}

The VAR Stability tests show that our VAR model is stable as the characteristic roots lie Within \pm 1 (see Fig 1 below) 
Inverse Roots of AR Characteristic Polynomial

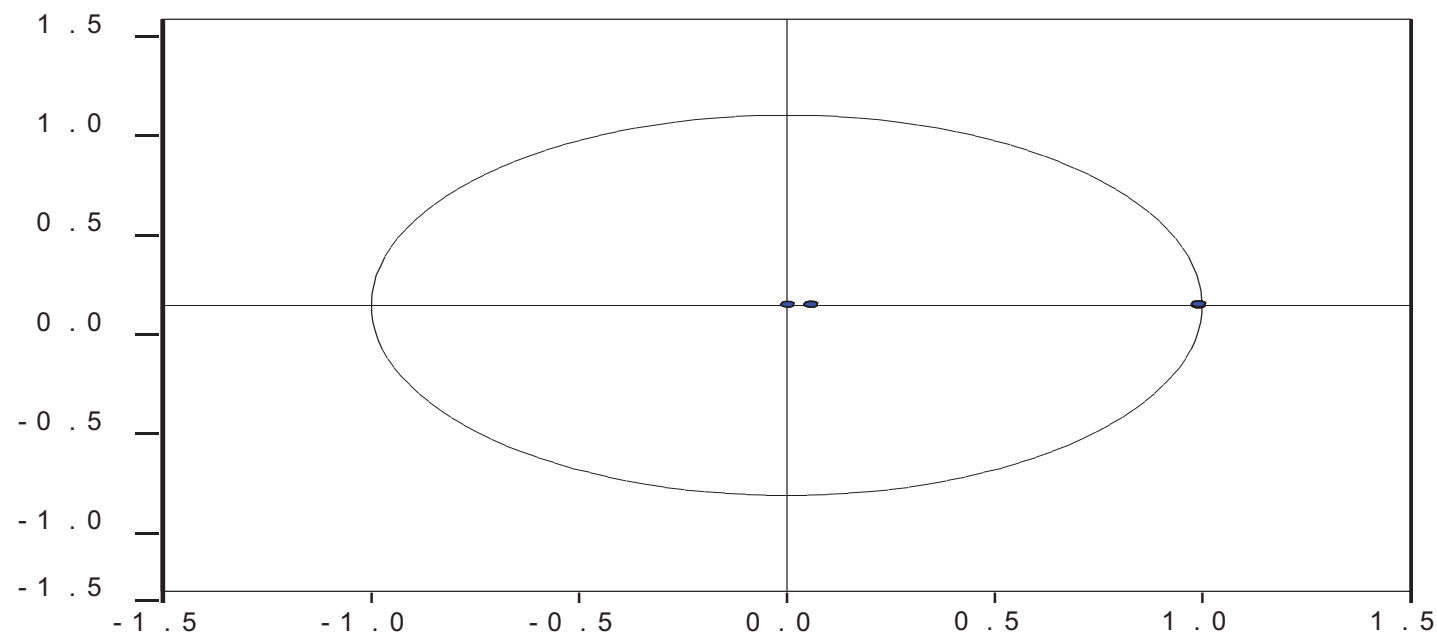

Fig 1: VAR Stability test through A R Characteristic roots

\section{(f) Granger Causality Test Results}

The test for Granger Causality has been carried out by taking the first difference of both the variables. The results (given in Table 6) show that causality flows from NSE Nifty to MCX COMDEX (We reject the Null of No Causality as ' $\mathrm{p}$ ' value is 0.0222$)$, however there is no causality from MCX COMDEX to NSE Nifty. Thus causality was Unidirectional from NSE Nifty to MCX COMDEX

TABLE 6 : VAR Granger Causality Results

Null : No Causality

Pairwise Granger Causality Tests

Lags: 2

\begin{tabular}{lrrr}
\hline Null Hypothesis: & Obs & F-Statistic & Prob. \\
\hline NSE_NIFTY does not Granger Cause MCX_COMDEX & 1234 & 3.82086 & $\mathbf{0 . 0 2 2 2}$ \\
MCX_COMDEX does not Granger Cause NSE_NIFTY & & 0.71599 & 0.4889
\end{tabular}

\section{CONCLUSION}

The present study made an attempt to investigate the linkages between movement between NSE Nifty (stock index) and MCX Comdex Futures (Commodity Index) for a five year period; April 2012 to March 2017 (Daily closing prices). The result of the study showed that both indices (stock index and commodity index) under study were found to be stationary at first difference and not at levels which resulted in further analysis in terms of cointegration. The Co-integration test results however showed that the two indices were also not cointegrated. The VAR results showed that MCX COMDEX is a function of its own lags till lag ' 2 ' \& is also being determined by Lag ' 4 ' and Lag ' 5 ' of the other variable NSE Nifty, while NSE Nifty's movement is determined by its own Lag till Lag ' 3 '. 
Granger Causality which was run at first difference showed that positive Causality flowing from NSE Nifty to MCX COMDEX, but not vice versa.

\section{POLICY IMPLICATIONS \& SCOPE FOR FURTHER RESEARCH}

The study is an attempt to investigate the linkages between daily movement of NSE Nifty (stock index) and MCX Comdex Futures (Commodity Index), the results could not detect any co-integration but unidirectional causal relation was detected from NSE Nifty to MCX COMDEX. These results are quite surprising and contrary to some of the studies on same lines on international markets, these results can be of tremendous benefit to investors who form a portfolio with the eye on diversification of assets. Since the results showed that the movement of the two variables of NSE Nifty (stock index) and MCX Comdex Futures (Commodity Index) is not cointegrated and only NSE Nifty impacts the MCX Comdex and not vice versa, it becomes an excellent tool for risk diversification and allocation of assets.

Another interesting thing which was observed is that NSE Nifty impacts the MCX COMDEX after three lags showing that the assimilation of information from the stocks is not immediate on the commodities and such a result can be extremely useful for those investors who have taken positions in stocks and shares and are looking at commodities for alternative investment avenues.

NSE Nifty impacting the MCX COMDEX after three lags also throws up an interesting area of research i.e.to identify the reasons behind such a phenomenon and how it compares with other countries in the developed or emerging markets. This also calls for studying the newer versions of causality like the test developed by Toda and Yamamoto (1995) and Dolado and Lutkepohl (1996) where a modified Wald test statistic (MWALD) is introduced which takes care of such instances.
Further in the current study, we have tried to develop a relation between variables with a data period of 5 years (April 2012-March 2017), the reason for taking this period was to avoid any irregular movement in prices due to the sub-prime crisis of 2008 and its after effects which were assumed to last for the next three years after the crisis. An interesting research area could be to take a larger period which also includes the sub-prime period, \& apply new techniques and methodologies which do consider in time series any structural breaks like due to subprime. Some of the techniques which have been developed include Gregory, A. W., \& Hansen, B. E. (1996) Co-integration, Zivot, E., \& Andrews, D. W. (2012) Unit root, Markov Switching Models etc. These techniques do take care of irregular price movements in time series, therefore by applying these new techniques one could get a substantial improvement in results.

\section{REFERENCES}

1) Belke, A., Bordon, I. G., \& Hendricks, T. W. (2010) Global liquidity and commodity prices-A cointegrated VAR approach for OECD countries. Applied Financial Economics, 20(3), 227-242.

2) Berlia, N., \& Sehgal, S. (2013) Information Transmission between India and International Commodities Futures Market: An Empirical Study for Bullion and Metals. Research in Applied Economics, 5(4), 149-175.

3) Chan, K. F., Treepongkaruna, S., Brooks, R., \& Gray, S. (2011) Asset market linkages: Evidence from financial, commodity and real estate assets. Journal of Banking \& Finance, 35(6), 1415-1426.

4) Creti, A., Joets, M., \& Mignon, V. (2013) on the links between stock and commodity markets' volatility. Energy Economics, 37, 16-28.

5) Dolado, J. J., \& Lütkepohl, H. (1996) Making Wald tests work for co-integrated VAR systems. Econometric Reviews, 15(4), pp. 369-386.

6) Granger, C.W.J; (1969) Investigating Causal Relations by Econometric Models and Cross Spectral Methods, Econometrica 37 PP 428-38 
7) Gregory, A. W., \& Hansen, B. E. (1996) Residualbased tests for co-integration in models with regime shifts. Journal of econometrics, 70(1), 99126.

8) Gujarati N. Damodar and Sangeetha (2007) Basic Econometrics, 4th edition, Tata McGraw Hill Education Pvt. Ltd

9) Kumar, B., \& Pandey, A. (2011) International linkages of the Indian commodity futures markets. Modern Economy, 2(03), pp 213

10) Mensi, W., Beljid, M., Boubaker, A., \& Managi, S. (2013). Correlations and volatility spill-overs across commodity and stock markets: Linking energies, food, and gold. Economic Modelling, 32, 15-22.

11) Pindyck, R. S., \&Rubinfeld, D. L. (2008). Econometric models and economic forecasts. McGraw-Hill.

12) Shahani Rakesh (2011) Financial Markets in India: A Research Initiative, Anamica Publishers, Delhi

13) Siqueira, E. L., Stosic T., Bejan, L., \& Stosic B. (2010). Correlations and cross-correlations in the
Brazilian agrarian commodities and stocks. Physica A: Statistical Mechanics and its Applications, 389(14), 2739-2743.

14) Thuraisamy, K. S., Sharma, S. S., \& Ahmed, H. J. A. (2013) The relationship between Asian equity and commodity futures markets. Journal of Asian Economics, 28, 67-75.

15) Toda, H. Y., \& Yamamoto, T. (1995) Statistical inference in vector auto-regressions with possibly integrated processes. Journal of econometrics, 66(1), pp. 225-250.

16) Vivian, A., Wohar, M.E., (2012) Commodity volatility breaks. Journal of International Financial Markets, Institutions \& Money 22, 395-422.

17) Zivot, E., \& Andrews, D. W. (2012) Further evidence on the great crash, the oil-price shock, and the unit-root hypothesis. Journal of Business \& Economic Statistics.

18) Websites: MCX (www.mcxindia.com), Yahoo Finance (in. finance. yahoo.com), NSE (www.nseindia.com.) 